\title{
The influence of fiber size on the behavior of the araucaria pine nut shell/PU composite
}

\author{
Giuliana Ribeiro Protzek1, Washington Luiz Esteves Magalhães², Paulo Rodrigo Stival Bittencourt ${ }^{3}$, \\ Salvador Claro Neto ${ }^{4}$, Rodrigo Lupinacci Villanova ${ }^{5}$, Elaine Cristina Azevedo**
}

\author{
1Programa de Pós-graduação em Engenharia Mecânica e de Materiais, Universidade Tecnológica Federal \\ do Paraná - UTFPR, Curitiba, PR, Brasil \\ 'Laboratório de Tecnologia da Madeira, Embrapa Florestas, Colombo, PR, Brasil \\ ${ }^{3}$ Departamento Acadêmico de Química, Universidade Tecnológica Federal do Paraná - UTFPR, \\ Medianeira, PR, Brasil \\ ${ }^{4}$ Instituto de Química de São Carlos, Universidade de São Paulo - USP, São Carlos, SP, Brasil \\ ${ }^{5}$ Departamento Acadêmico de Mecânica, Universidade Tecnológica Federal do Paraná - UTFPR, \\ Curitiba, PR, Brasil \\ *helunica@yahoo.com.br
}

\begin{abstract}
The use of araucaria pine nut shell in polymer composites may increase the pine nut value and help protec araucaria (Araucaria angustifolia) itself, which is an endangered species. The aim of this work is to study the influence of the size of pine nut shell fiber on the mechanical properties of composites made of this shell and polyurethane derived from castor oil. Composites with different polyurethane contents were manufactured with dried untreated pine nut shell sieved through 30 and 50 mesh sieves ( 0.6 and $0.3 \mathrm{~mm}$, respectively). Composites were shaped by mechanical mixing of the components followed by hot pressing. Properties such as density, water absorption, and flexural strength were measured. Specimens were also characterized by SEM, FTIR, and TGA. The flexural strength of PU/0.3mm pine nut shell composites with 30\% PU (wt\%) was $57.7 \mathrm{MPa}$, and their water absorption was $7.37 \%$ after 24 hours of immersion.
\end{abstract}

Keywords: araucaria pine nut shell, composite, castor oil, polyurethane, mechanical properties.

How to cite: Protzek, G. R., Magalhães, W. L. E., Bittencourt, P. R. S., Claro Neto, S.,Villanova, R. L., \& Azevedo, E. C. (2019). The influence of fiber size on the behavior of the araucaria pine nut shell/PU composite. Polimeros: Ciência e Tecnologia, 29(2), e2019025. https://doi.org/10.1590/0104-1428.01218

\section{Introduction}

The development of products with low cost, reduced energy consumption and life cycle sustainability is driven by the worldwide concern with the environment and human health ${ }^{[1-3]}$. Biodegradable composites are environmentally friendly ${ }^{[1]}$, can be made from renewable sources, and degraded by the action of microorganisms ${ }^{[2,4]}$.

Composites made of biodegradable polymers and reinforced by natural fibers are an attractive option, since these fibers have some advantages when compared to synthetic ones, such as lower density, lower cost, and lower abrasivity during manufacturing. Besides, natural fibers are derived from renewable sources, are not toxic, and do not cause environmental impacts ${ }^{[1,5-7]}$.

Fernandes et al. ${ }^{\left[{ }^{8]}\right.}$ analyzed the influence of silica nanoparticles on the compatibility between sisal fibers and high density polyethylene. They observed that thermal properties of HDPE did not change because of the presence of sisal fibers and silica nanoparticles in the composite. The different chemical treatments in sisal fibers and the presence of silica nanoparticles resulted in improved

mechanical properties and water uptake decrease in the composites, when comparing to HDPE.

Spadetti et al. ${ }^{[9]}$ investigated thermal and mechanical properties of composites made of both virgin and recycled polypropylene reinforced with cellulose fiber. The results showed that recycled polypropylene composites with $30 \%$ (wt $\%$ ) cellulose fibers and virgin polypropylene composites with $20 \%$ (wt $\%$ ) of cellulose fibers had a significant increase in storage modulus values (E') and degree of crystallinity $(\chi c)$, indicating a higher mechanical strength in these composites. However, the stiffness specimens of the material with $40 \%$ (wt $\%$ ) of cellulose fibers decreased. These results were confirmed by SEM, where some agglomeration of the cellulose fibers within the matrix was observed. Both glass transition temperature ( $\mathrm{Tg}$ ) and crystalline melting temperature (Tm) of composites did not change.

Mano et al. ${ }^{[10]}$ studied the morphological, mechanical, and thermal properties of composites made of polypropylene reinforced with curaua fibers treated with maleic anhydride grafted polypropylene. The use of PP-g-MA as a compatibilizer significantly increased fiber/matrix adhesion; however, 
mechanical properties were only slightly improved when comparing to composites produced without compatibilizer.

Beltrami et al. ${ }^{[4]}$ studied the morphological, mechanical, and thermal properties of composites made of PHBV and curaua fibers with alkaline treatment. Results indicate that the alkaline treatment improved the adhesion of the fibers to the matrix, which significantly improved the mechanical properties of the composites. However, $\mathrm{NaOH}$ concentrations of $\mathrm{NaOH}$ different from $5 \%$ may have a deleterious effect on the mechanical properties of the fibers and composites.

Mei \& Oliveira ${ }^{[7]}$ studied the morphological, mechanical and thermal properties and the biodegradability of composites containing chemically treated coffee grounds and poly(E-caprolactone). Thermal analysis showed that the addition of coffee grounds increased the maximum peak of thermal degradation by $10^{\circ} \mathrm{C}$ when compared to pure polymer. Biodegradability was higher for specimens containing acetylated coffee grounds.

Load transfer from the polymer matrix to the fibers greatly depends on the matrix-fiber interaction ${ }^{[4]}$. Natural fibers are hydrophilic, while most polymer matrixes are hydrophobic ${ }^{[8,11]}$. As a result, the adhesion between those materials is compromised, decreasing the mechanical properties of the composite ${ }^{[5,6]}$. One possible way to improve such interaction if by modifying the surface of the fibers by means of physical ${ }^{[12,13]}$ or chemical methods ${ }^{[4,5,7]}$.

Polyurethane derived from castor oil is a biodegradable polymer produced from renewable sources, and it is harmless to human health and to the environment, since no volatile organic compounds are liberated in its synthesis ${ }^{[6,14,15]}$. During polyurethane polymerization in the presence of vegetable fibers, crosslinks may result from the reaction of active hydrogens from hydroxyl or carboxyl groups from lignin and PU free isocyanate. Such reactions may improve matrix-fiber interaction, leading to better load transfer and enhanced mechanical properties. This is the reason no previous treatments on the fibers and no coupling agents are needed in this type of composites ${ }^{[11,16]}$.

Marinho et al. ${ }^{[15]}$ studied physical and thermal properties of composites made of PU based on castor oil and bamboo particles without any previous treatment. This approach minimizes the negative impact to the environment, since a solvente free polymer is obtained. The association of PU and bamboo particles produced the expected effects, including a decrease in moisture content, swelling and water absorption of bamboo as PU content increased.

Zau et al. ${ }^{[17]}$ analyzed the chemical, physical and mechanical properties of agglomerated panels made of cumaru wood residues with PU derived from castor oil. They produced panels with different amounts of residues $(1000,1300,1500 \mathrm{~g})$ and resin content $(10,12.5$ and $15 \%)$. Higher mechanical properties were achieved for panels with $1500 \mathrm{~g}$ of residue and $15 \% \mathrm{of}$ resin, and the values exceed the minimum specified by the NBR 14810-3 (2006), confirming their potential in producing particleboards.

Araucaria angustifolia is a tree from southern Brazil ${ }^{[18]}$. It is an endangered species, and there are legal restrictions concerning the use of its wood; therefore, incentives are given to the commercialization of its seed, the pine nut ${ }^{[19]}$. Pine nut is a nutritious food, containing mainly starch and low amounts of sugars and lipids in its composition ${ }^{[20]}$. About 700 tons/year of pine nut shell residue are disposed of in south Brazil ${ }^{[21]}$. The use of this pine nut shell in polymer composites can reduce the amount of discarded material in the environment and increase its value. Araucaria angustifolia is an endangered species, mainly because of illegal exploitation and commercialization of its wood. The use of pine nut shell may help to preserve the trees, since it can be a source of income and avoid cutting down trees. Composites made with pine nut shell can be used in handicrafts and furniture, replacing MDF, which has a significant impact on the environment.

The aim of this work is to evaluate the effect of pine nut shell size on mechanical, physical, and thermal properties of composites made of castor oil polyurethane and pine nut shell. Two different sizes of pine nut shell were used, i.e., those passing through 30 and 50 mesh $(0.6$ and $0.3 \mathrm{~mm}$ sieve opening), and the composites were produced with varying amounts of PU by means of mechanical mixing and hot pressing. Several characterization tests were carried out, namely: volumetric density, water absorption, flexural strength, thermogravimetric analysis (TGA), Fourier-transform infrared spectroscopy (FTIR), X-ray diffraction (XRD), and scanning electron microscopy (SEM).

\section{Materials and Methods}

\subsection{Materials}

Castor oil-based PU resins employed in this work were developed by the Group of Analytic Chemistry and Technology of Polymers - USP . Polyurethane is a bi-component resin obtained by the reaction of a polyol and an isocianate terminated pre-polymer. Currently, both pre-polymer and polyol are produced by Cequil, from Araraguara-SP, Brazil. The pre-polymer used is based on the diphenylmethanodiisocyanate (MDI). Polyols are polyesters derivate from castor oil with different amount of functional hydroxyl groups. The pre-polymer was synthesized from diphenylmethanediisocyanate (MDI) and prepolymerized with polyols, also derived from castor oil, keeping a percentage of free isocyanate for later reaction. PU Polibond ${ }^{\circledR}$ is athermoset adhesive. Polymer preparation was made according to the supplier instructions. Pine nut shell was donated by Embrapa Florestas, from Colombo-PR, Brazil. The shell was crushed in a knife mill suited for grains and dry materials. Crushed shells were classified through 30 and 50 mesh sieves ( 0.6 and $0.3 \mathrm{~mm}$ aperture), dried at $100^{\circ} \mathrm{C}$ for 24 hours and kept in a desiccator until used No chemical or physical treatments were performed in the fibers.

\subsection{Composites production}

Composites with $50 \%, 60 \%$, and $70 \%$ of pine nut shell (wt $\%$ ) were produced by mixing the pine nut shell to the castor oil polyurethane in a MH-100 series 6069 mixer (MH Equipamentos) $3200 \mathrm{rpm}$ for 20s . The mixture was shaped in a hot press (Marconi Equipamentos, model MA 098/AR15, under $6 \mathrm{MPa}$ pressure at $70^{\circ} \mathrm{C}$ for 20 minutes, which was sufficient to allow the system to cure. 


\subsection{Characterization of composites}

The density of the composites was measured according to EN 323:2002 Standard, and the water absorption was determined according to EN 317: 2002 Standard. Tests were conducted at a room temperature. Five specimens of each composite were cut from a plate, as $50 \mathrm{X} 50 \mathrm{~mm}$ samples with unsealed borders. The initial thickness (the thickness is measured close to the center of the specimen) was measured and the samples were weighted before being submerged in distilled water for $2 \mathrm{~h}$. After immersion, the water on the surface of the samples was removed, and the samples were immediately weighed, measured, and immersed in water again. After $22 \mathrm{~h}$ they were removed, pat dried, measured and weighted again.

Flexural tests were performed according to the ASTM D790-03 standard in an EMIC DL10000 universal tester, with load cell of $20 \mathrm{kN}$ and test speed of $5 \mathrm{~mm} / \mathrm{min}$.

Scanning Electron Microscopy was performed in a Zeiss microscope, model EVO MA 15. Specimens were gold sputtered prior to observation. SEM was used to investigate the surface of fibers after drying and the fracture surface of the composites after flexural test.

Thermogravimetric analyses (TGA) were carried out in a Perkin Elmer STA 6000 thermo scale, and the following parameters were used: Specimen mass: 5.0 to $10.0 \mathrm{mg}$; Temperature range $30^{\circ} \mathrm{C}$ to $800{ }^{\circ} \mathrm{C}$; Heating rate $10 \mathrm{C} / \mathrm{min}$; Flow of $\mathrm{N} 2$ atmosphere $100 \mathrm{~mL} / \mathrm{min}$.

FITR analyses were carried out in a Varian infrared spectrometer model 640-IR, equipped with a diamond ATR accessory from PIKE, with a resolution of $4 \mathrm{~cm}^{-1}$.

A Shimadzu X-ray diffractometer, model XRD-700, with $\mathrm{Cu} \mathrm{K} \alpha$ radiation, operating at $40 \mathrm{kV}$ and $20 \mathrm{~mA}$ was used to analyze the crystallinity of the specimens. The degree of crystallinity was determined by the technique proposed by Hermans and described by Poletto ${ }^{[22]}$.

\section{Results and Discussions}

\subsection{Density measurements}

The density of the composites is shown in Table 1 . It ranged from 1155.50 to $1214.08 \mathrm{~kg} / \mathrm{m}^{3}$. According to Brasil et al. ${ }^{[23]}$, the density of the pine nut shell powder is $180 \mathrm{~kg} / \mathrm{m}^{3}$. PU density is $1090 \mathrm{~kg} / \mathrm{m}^{3}$ and pine nut shell is $900 \mathrm{~kg} / \mathrm{m}^{3}$.

The data shown in Table 1 indicates that independent of the amount of fiber and its size, the density vary slightly, and increases a little when compared to the PU.

Table 1. Composites density.

\begin{tabular}{ccc}
\hline Sieve & PU (wt \%) & Density $\left(\mathbf{K g} / \mathbf{m}^{3}\right)$ \\
\hline- & 100 & $1090.00 \pm 0.03$ \\
0.6 & 30 & $1194.31 \pm 24.66$ \\
0.6 & 40 & $1155.50 \pm 57.30$ \\
0.6 & 50 & $1155.63 \pm 14.15$ \\
0.3 & 30 & $1200.64 \pm 21.80$ \\
0.3 & 40 & $1213.78 \pm 15.45$ \\
0.3 & 50 & $1184.55 \pm 29.31$ \\
\hline
\end{tabular}

The density of the composite with the addition of pine nut shell powder is greater than the density of PU alone. According to the rule of mixtures, the density of the composite should be lower than the PU. Bubbles are generated during the production of PU because of the reaction of isocyanate with air humidity, as observed by Merlini et al. ${ }^{[16]}$ and Marinho $^{[15]}$. However, it was possible to obtain a slightly better densification of the composites because of the high speed $(3200 \mathrm{rpm})$ of the mechanical mixing process, since the fine powder of the pine nut shell occupied the spaces of the bubbles generated in the polymerization process, thus allowing the incorporation of $70 \%$ of particles of $0.3 \mathrm{~mm}$. The standard technique used to produce composites with thermoset matrix is manual mixing of the components followed by pressing. The technique employed in this work, i.e., mechanical mixing, allowed a greater incorporation of fine particles within the polymer matrix, increasing the density of the material when compared to neat PU.

\subsection{Water absorption determination}

The results obtained from the water absorption test for 2 and 24 hours for the composites with different fiber particle sizes are shown in Figure 1.

Our data indicate that water absorption increases with time, fiber content and decreasing particle size. This is to be expected since water absorption is attributed to the lignocellulosic component. So, water uptake should increase with the amount of fiber and its surface area. Even though the standard used in this work suggest that water uptake measurements should be made after $2 \mathrm{~h}$ and $24 \mathrm{~h}$ of immersion, we performed measurements up to saturation, as the ASTM D570 standard suggests. We observed that composites absorb water rapidly within the first 24 hours, and after that, a saturation level of $12.5 \%$ is reached for a sample with $50 \% \mathrm{PU}$, and no further water uptake is observed, even after 15 days of immersion.

Composites with $0.6 \mathrm{~mm}$ and $0.3 \mathrm{~mm}$ fibers and $50 \%$ PU showed the lowest water absorption in 2 and 24 hours immersion, and this is attributed to the higher amount of PU of these composites.

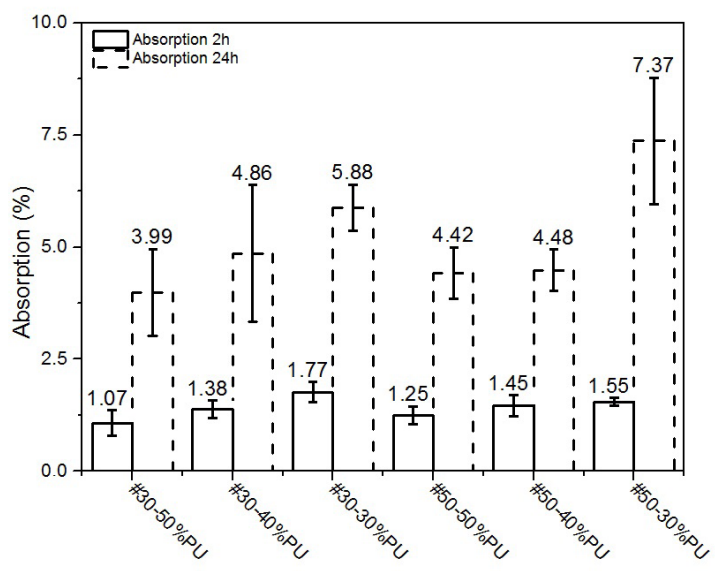

Figure 1. Water absorption test results. 2 and 24 hours of test for composites with $0.6 \mathrm{~mm}(\# 30)$ and $0.3 \mathrm{~mm}$ (\#50) fibers. 
Water absorption is lower for the composites made with $0.6 \mathrm{~mm}$ fiber. Bigger fibers have less surface area, resulting in less water absorption. Composites made of $0.3 \mathrm{~mm}$ fiber and $40 \%$ PU and 50\% PU showed very similar water absorption values.

Water absorption occurs only by the pine nut shell particles, because PU does not absorb water ${ }^{[15]}$. The values obtained indicate that the fibers were covered by PU efficiently regardless of the amount and granulometry of the fibers used and this is attributed to the mixing technique employed here. Marinho ${ }^{[15]}$ has studied the water absorption of manually mixed PU and bamboo composites using the same PU employed here and obtained water uptake values of of $22.9 \%$ for composites made with $80 \%$ (wt $\%$ ) of $2.7 \mathrm{~mm}$ bamboo fibers Measurements were made according to the ASTM D570 standard at room temperature.

\subsection{Flexural strength measurements}

The flexural strength of the composites is shown in Figure 2. The flexural strength of $\mathrm{PU}$ is $42 \mathrm{MPa}^{[11]}$, and the highest flexural resistance was obtained for the composite made with $0.3 \mathrm{~mm}$ pine nut shell and $30 \%$ PU. When compared to PU, the increase in flexural strength was $27 \%$.

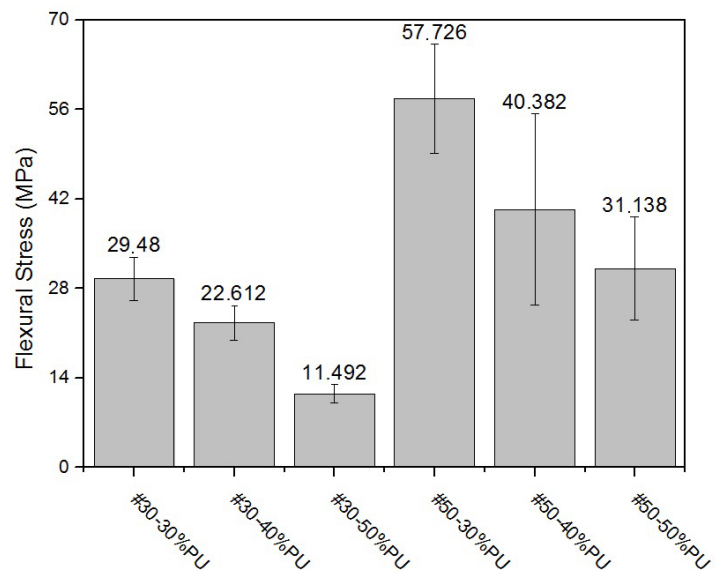

Figure 2. Flexural strength of the composites.

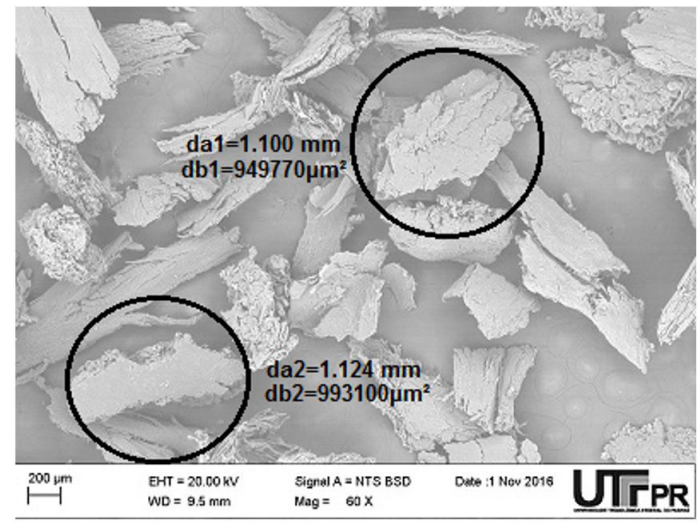

(a)
The data shown in Figure 2 indicate that the flexural strength of the composites increases with increasing fiber content and decreasing filler particle size. This is associated with improved packing of finer fibers, as shown in Figure 3. Vasco et al. ${ }^{[11]}$ and Merlini et al. ${ }^{[16]}$ observed that an interaction between hydroxyl groups from the fibers and PU isocyanate occurs, promoting chemical adhesion between the polymer matrix and the reinforcement. Smaller fibers favor packing, distribution and homogenization of the reinforcement within the matrix, resulting in better adhesion between materials ${ }^{[24]}$.

The fibers were not treated to improve the interface with the PU, and even so displayed higher flexural strength values than those of other composites made with natural fibers, such as the composite developed by Zau et al. ${ }^{[17]}$, that found flexural strength of $14 \mathrm{MPa}$ for composites made with $85 \%$ sugarcane bagasse and castor oil polyurethane adhesive-based particulate. This shows that the mixing technique is efficient for the production of fine particulate composites with larger amounts than usual.

\subsection{SEM}

The micrographs of the fracture surfaces after three-point flexural test of composites made with $0.6 \mathrm{~mm}$ pine nut shell and $30 \%$ and $50 \%$ PU are shown in Figures $4 \mathrm{a}$ and $4 \mathrm{~b}$, respectively. In Figure $4 \mathrm{a}$, a good fiber-matrix interface can be observed, as well as the presence of voids resulting from the fibers that were detached from the matrix during the tests. The fracture of the PU matrix and the presence of bubbles can also be observed.

For the composite with 50\% PU (Figure 4b), the good fiber-matrix interface, as well as the voids from detached fibers, can also be observed. PU displayed brittle fracture, as demonstrated by the mirror-like areas close to stress concentrators such as bubbles and impurities of the surface of the fiber. The reduction in the composite mechanical strength could also be attributed to these characteristics.

Figures $5 \mathrm{a}$ and $5 \mathrm{~b}$ show the fracture surfaces after bending test of composites made with $0.3 \mathrm{~mm}$ pine nut shell and 30\% PU and 50\% PU, respectively. In Figure 5a, it is not possible to observe the presence of voids or holes

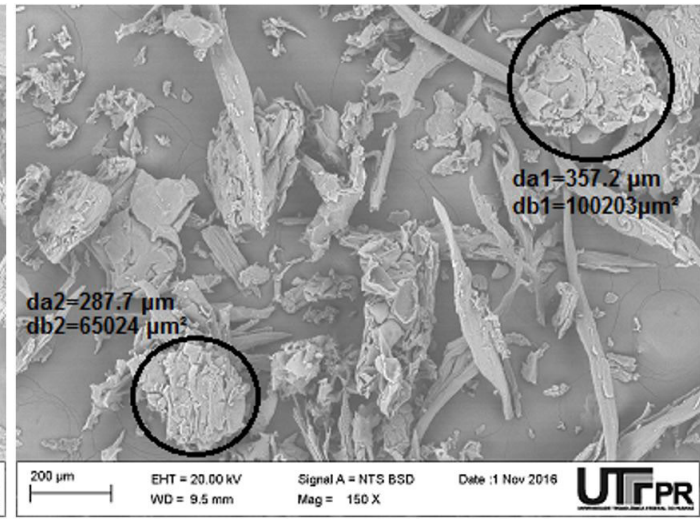

(b)

Figure 3. SEM micrographs of $0.6 \mathrm{~mm}$ (a) and $0.3 \mathrm{~mm}$ (b) particles. 


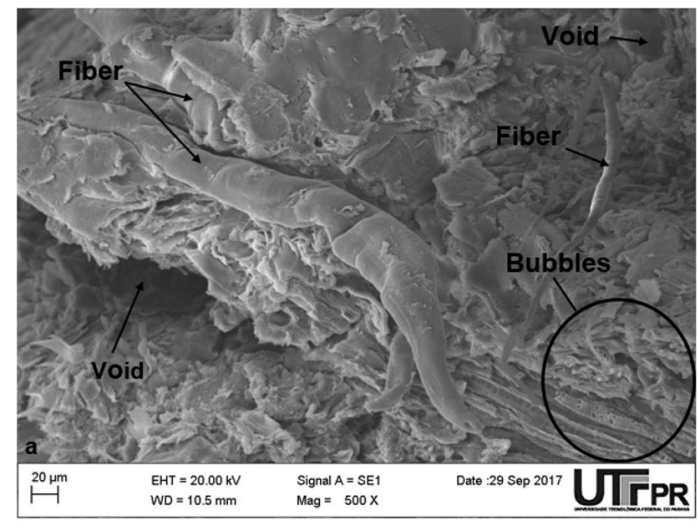

(a)

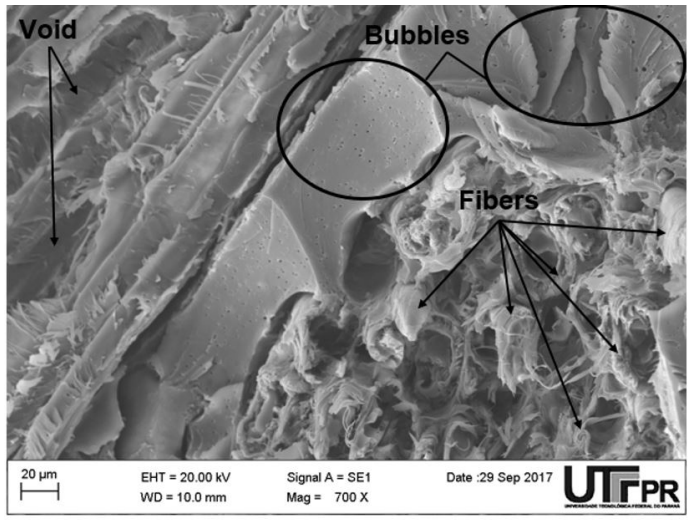

(b)

Figure 4. SEM microgaphs of the fracture surfasse of $0.6 \mathrm{~mm}$ composites: (a) $30 \% \mathrm{PU}$, (b) $50 \% \mathrm{PU}$.

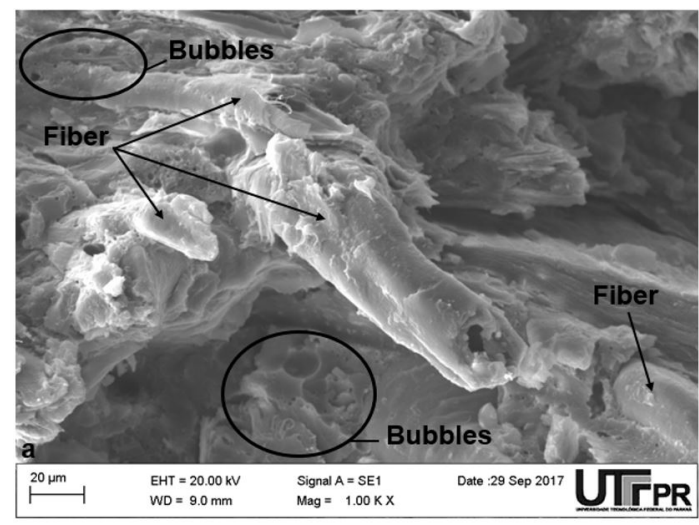

(a)

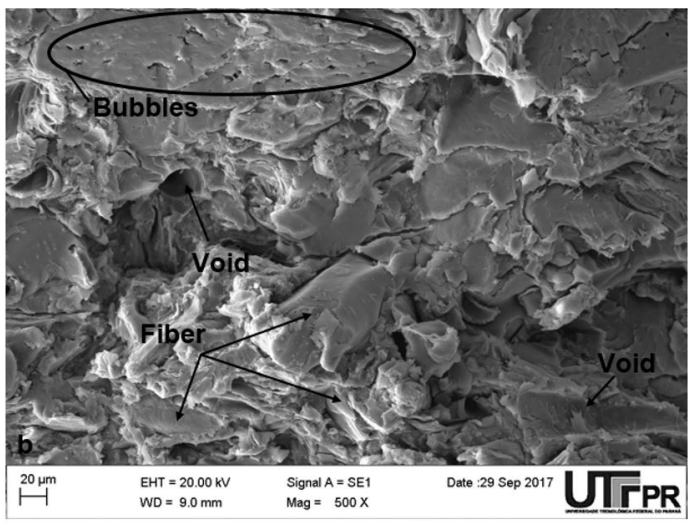

(b)

Figure 5. SEM microgaphs of the fracture surfasse of $0.3 \mathrm{~mm}$ composites: (a) $30 \% \mathrm{PU}$, (b) $50 \% \mathrm{PU}$.

in the fiber-matrix interface, indicating that the fibers were well covered by the polymer and some chemical interaction between the components might have occurred. This increases the adhesion between fibers and polymer, improving mechanical properties by means of a better distribution of mechanical loads. Some small bubbles can also be observed throughout the composite. In Figure $5 b$, the interaction between the fibers and the matrix can be observed, was well as the presence of voids resulting from fiber detachment. PU fracture is brittle, and there are bubbles all over the matrix. Although the homogenization technique has been efficient to promote the incorporation of the fiber into the matrix, it does not avoid the formation of small bubbles, which are inherent to the PU production process.

\subsection{TGA}

The results from the thermogravimetric analyses for $\mathrm{PU}$ and pine nut shell are shown in Figures $6 \mathrm{a}$ and $6 \mathrm{~b}$, respectively.

Two distinct events can be observed for the PU, the first one occurring between $250^{\circ} \mathrm{C}$ and $350^{\circ} \mathrm{C}$ with a mass loss of $40 \%$. In this temperature range, the urethane bonds are broken ${ }^{[25]}$. The second event takes place between $350^{\circ} \mathrm{C}$ and $500^{\circ} \mathrm{C}$ with a mass loss of $60 \%$, and this is attributed to the decomposition of the ester bonds present in polyol ${ }^{[26]}$.

Regarding the pine nut shell, an initial mass loss event at $30^{\circ} \mathrm{C}$ is observed, which is associated with the loss of absorbed water, typical of lignocellulosic materials ${ }^{[7]}$. In the range from $170^{\circ} \mathrm{C}$ to $295^{\circ} \mathrm{C}$, there is another mass loss event related to the degradation of hemicellulose $\mathrm{e}^{[5]}$. From $295^{\circ} \mathrm{C}$ to $330^{\circ} \mathrm{C}$, cellulose degrades ${ }^{[27]}$, while lignin degrades between 330 and $500^{\circ} \mathrm{C}^{[28]}$. The remaining $27 \%$ of mass can be considered carbonaceous residues.

In Figure 7, the TGA and DTG curves of 30 mesh and 50 mesh composites are shown. From the figure, it is possible to observe that the thermal stability of the composites lies between those of $\mathrm{PU}$ and pine nut shell. The first event occurs between $50^{\circ} \mathrm{C}$ to $150^{\circ} \mathrm{C}$, and it is related to the presence of water [11]. The next event occurred between $150^{\circ} \mathrm{C}$ and $394^{\circ} \mathrm{C}$ and might have happened because of the degradation of the pine nut shell. The third event occurs form $394^{\circ} \mathrm{C}$ to $500^{\circ} \mathrm{C}$ and is probably related the degradation of the PU. 


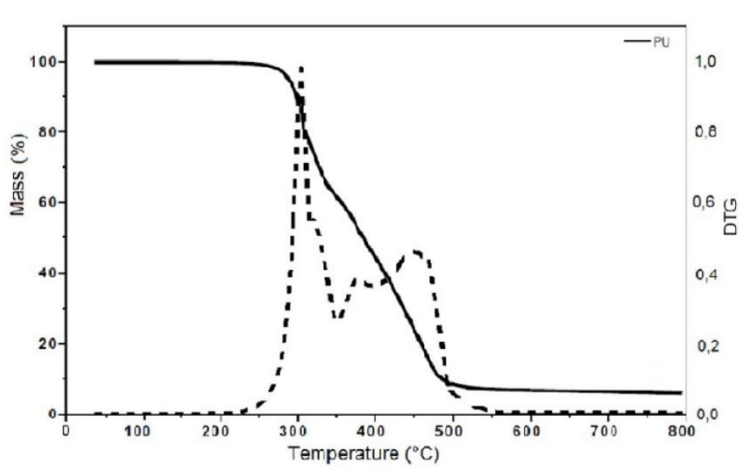

(a)

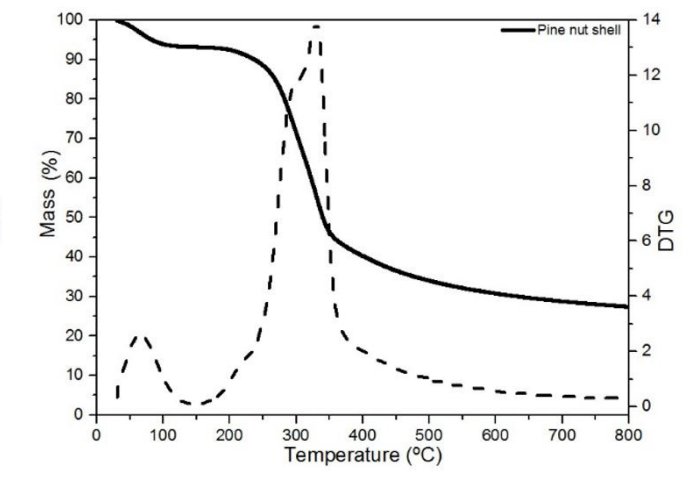

(b)

Figure 6. Thermogravimetric data for (a) PU and (b) pine nut shell.

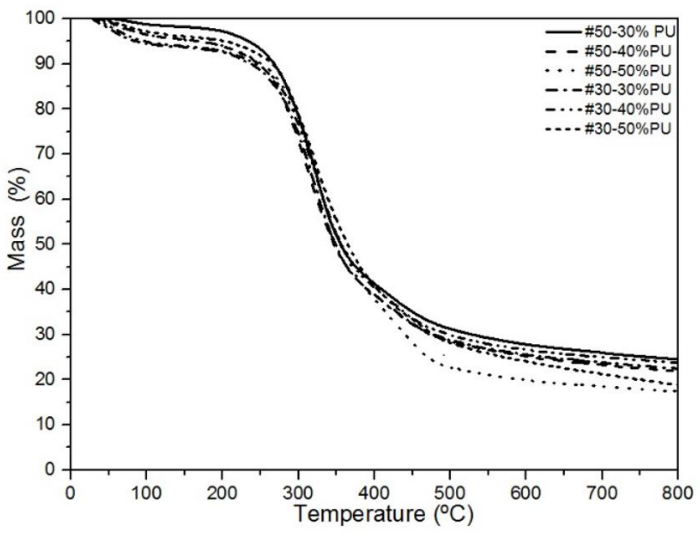

(a)

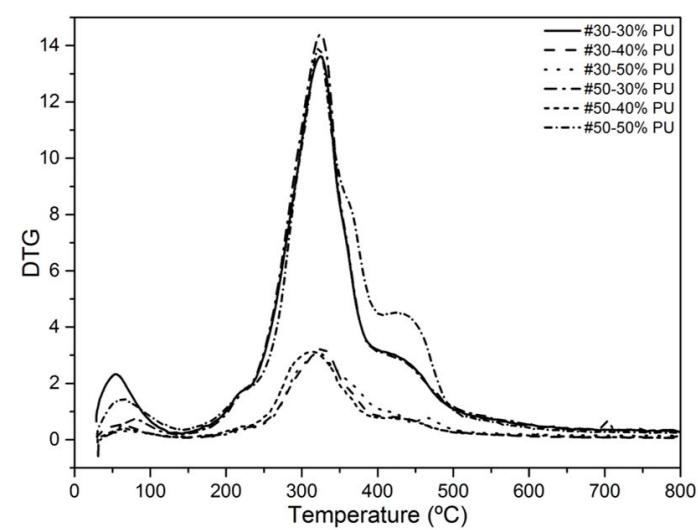

(b)

Figure 7. (a) TG and (b) DTG curves of $0.6 \mathrm{~mm}(\# 30)$ and $0.3 \mathrm{~mm}$ (\#50) composites.

Particle size does not influence the thermogravimetry of the composites. The initial mass loss of the composites occurs around $150^{\circ} \mathrm{C}$, which is expected, since the thermal stability of the fibers of pine nut shell is around $170{ }^{\circ} \mathrm{C}$.

\subsection{FTIR}

FTIR spectrograms of PU and pine nut shell are shown in Figure 8. For PU, an O-H band is observed at $3320 \mathrm{~cm}^{-1}$. The bands at 2920 and $2850 \mathrm{~cm}^{-1}$ are associated with $\mathrm{C}-\mathrm{H}$ symmetrical and asymmetrical stretching ${ }^{[27]}$. The isocyanate band is located at $2270 \mathrm{~cm}^{-1}[16]$, and the urethane bands at 1700,1596 , and $1520 \mathrm{~cm}^{-1}$ are related to the $\mathrm{C}=\mathrm{O}$ and $\mathrm{N}-\mathrm{H}$ stretching, and they tend to increase with the crosslinking of the polyurethane chains ${ }^{[16,29]}$.

For the pine nut shell, a band at $3340 \mathrm{~cm}^{-1}$ associated to lignin phenols and cellulose and hemicellulose hydroxyls can be observed ${ }^{[30]}$.

The band at $2930 \mathrm{~cm}^{-1}$ is related to the $\mathrm{C}-\mathrm{H}$ bond stretching present in cellulose and hemicellulose $\mathrm{e}^{[5]}$. The peak at $1610 \mathrm{~cm}^{-1}$ is related to $\mathrm{C}=\mathrm{O}$ carbonyl bonds of the lignin ${ }^{[16]}$, while the peak at $1024 \mathrm{~cm}^{-1}$ corresponds to the $\mathrm{C}-\mathrm{H}$ aromatic group and to the stretching of primary alcohols of lignin ${ }^{[5]}$.
The spectrograms of $0.6 \mathrm{~mm}$ and $0.3 \mathrm{~mm}$ composites are shown in Figure 9a and Figure $9 \mathrm{~b}$ respectively. There was a reduction in the intensity of the $\mathrm{NCO}$ and $\mathrm{OH}$ peaks of the composites. Such reduction might indicate a chemical affinity between O-H and N-C-O groups of the materials which the composites are made of.

\subsection{XRD}

The XRD diffractograms of PU, pine nut shell fibers, and composites (both 0.6 and 0.3 ) are shown if Figure 10.

Polyurethane results from the chemical reaction between an isocyanate and a hydroxyl group. In this polymerization, a compound containing two or more isocyanate groups per molecule reacts with a polyol or a polyfunctional alcohol. Any changes in the polyol and pre-polymer ratio $(-\mathrm{NCO} /-\mathrm{OH})$ cause substantial morphological changes in the PU chains, leading to modifications in mechanical properties of the material. The degree of crosslinking is controlled by the isocyanate group (-NCO) of the pre-polymer and by the hydroxyl group of the polyol, and, in the composites with pine nut shell, a reation with the $\mathrm{OH}$ of the pine nut shell particles also occurs. 


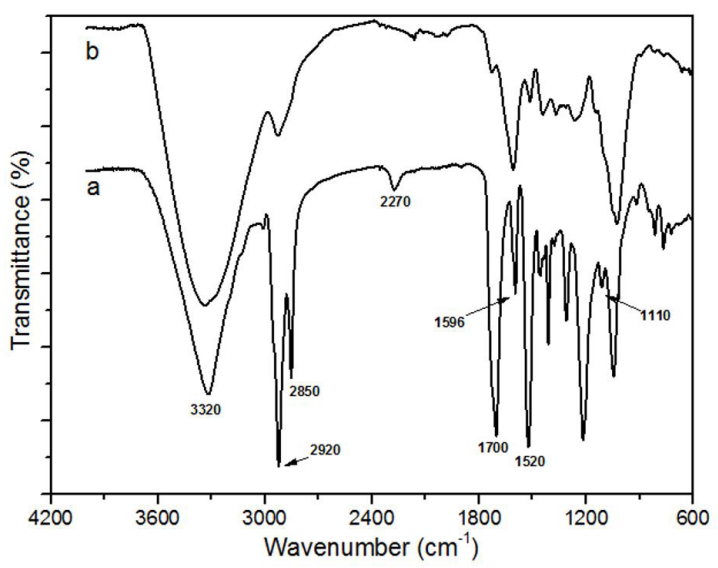

Figure 8. FTIR spectra of (a) PU and (b) pine nut shell.
As demonstrated in Figure 10, the diffraction profiles show an amorphous broad shoulder, diffused diffraction with a maximum at $2 \theta=20^{\circ}$. It is likely that some soft segment-hard segment phase mixing could occur in the system disturbing the soft segment crystallization ${ }^{[26,29]}$. This may account for the broader diffraction peaks shown in the diffracttograms. For ordinary synthetic polymers, the nonuniformity of the molecules makes it impossible to form perfect single crystals. As a result, amorphous and crystalline phases are present in a real polymers, and these entities have complex organization.

In the pine nut shell diffractograms, peaks at $16^{\circ}$ and $22^{\circ}$ are observed, corresponding to the amorphous and crystalline regions of cellulose, respectively ${ }^{[31]}$. Such behavior is similar to semicrystalline structures.

The degree of crystallinity of the composites are shown in Table 2, The determination of the amorphous to crystalline percentage was obtained from peak area ratios. It can be

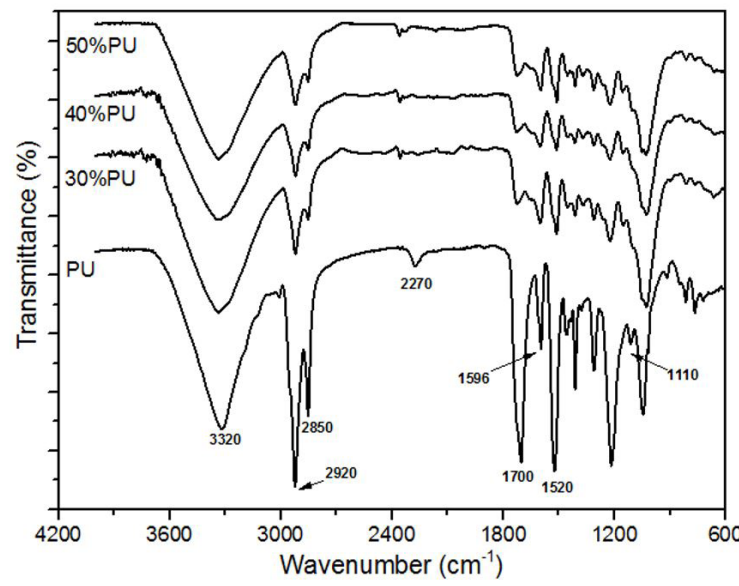

(a)

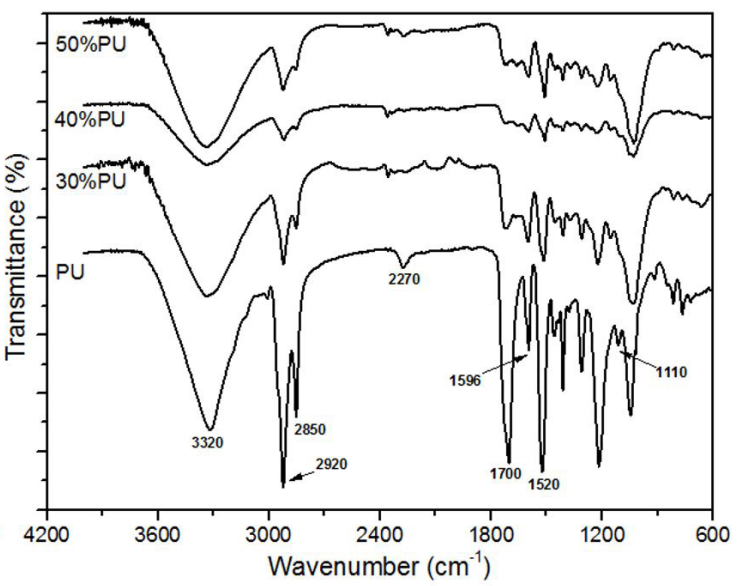

(b)

Figure 9. FTIR spectra of PU and composites: (a) $0.6 \mathrm{~mm}$ and (b) $0.3 \mathrm{~mm}$.

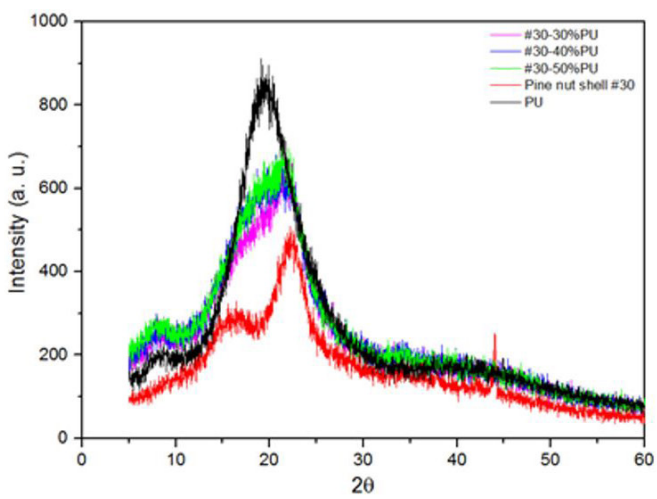

(a)

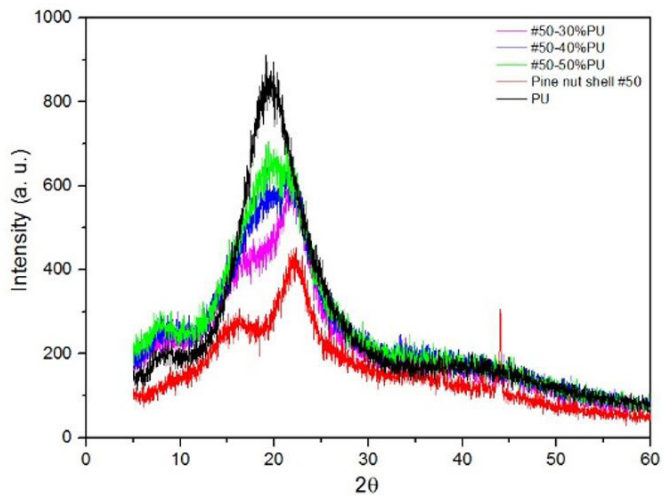

(b)

Figure 10. XRD diffractograms of PU, pine nut shell fibers, and composites: (a) $0.6 \mathrm{~mm}$ (\#30) and (b) $0.3 \mathrm{~mm}$ (\#50). 
Table 2. Degree of crystallinity.

\begin{tabular}{ccc}
\hline Sieve & PU (\%) & $\mathbf{X}_{\mathbf{c}} \mathbf{( \% )}$ \\
\hline 0.6 & 0 & 36 \\
0.6 & 30 & 32 \\
0.6 & 40 & 34 \\
0.6 & 50 & 31 \\
0.3 & 0 & 36 \\
0.3 & 30 & 32 \\
0.3 & 40 & 32 \\
0.3 & 50 & 32 \\
- & 100 & 31 \\
\hline
\end{tabular}

observed that the composites display a small increase of crystallinity when compared to neat PU, indicating that structural changes occurred during the production process. The results indicate that filler particle size does not affect the degree of crystallinity.

\section{Conclusions}

The aim of this work was to investigate the mechanical, physical and thermal properties of properties of PU/pine nut shell composites as a function of fiber content and granulometry. Density was higher for composites made with finer fibers, and water absorption increased with time, fiber content and decreasing particle size. Flexural strength was higher for composites with higher amount of fibers and smaller sizes. A good fiber-matrix interface, as well as the presence of micro bubbles, which are inherent of the PU production process, was shown by the SEM micrographs. TGA analyses showed that PU and all composites were thermally stable up to $150^{\circ}$. The reduction in the intensity of the $\mathrm{NCO}$ and $\mathrm{OH}$ peaks observed in FTIR analyses indicates reaction between these groups. The results indicate that the composite degree of crystallinity was not affected byfiller particle size.

\section{Acknowledgements}

The authors would like to thank CAPES, FAPESP, Fundação Araucária, and CNPQ for financial support, CEQUIL for donating the PU used in this work, Embrapa Florestas for the equipments and for donating the pine nut shell, Centro Multiusuário de Caracterização de Materiais from UFPR-CT for the SEM analyses, DAQUI from Campus Medianeira of UTFPR, and LAMAQ from Campus Curitiba/Ecoville for the equipments.

\section{References}

1. Lemos, A. L., \& Martins, R. M. (2014). Desenvolvimento e caracterização de compósitos poliméricos à base de Poli(Ácido Lático) e fibras naturais. Polímeros: Ciência e Tecnologia, 24(2), 190-197. http://dx.doi.org/10.4322/polimeros.2014.047.

2. Ligowski, E., Santos, B. C., \& Fujiwara, S. T. (2015). Materiais compósitos a base de fibras da cana-de-açúcar e polímeros reciclados obtidos através da técnica de extrusão. Polímeros: Ciência e Tecnologia, 25(1), 70-75. http://dx.doi. org/10.1590/0104-1428.1605.

3. Dong, C., \& Davies, I. J. (2012). Flexural properties of macadamia nutshell particle reinforced polyester composites.
Composites. Part B, Engineering, 43(7), 2751-2756. http:// dx.doi.org/10.1016/j.compositesb.2012.04.035.

4. Beltrami, L. V. R., Scienza, L. C., \& Zattera, A. J. (2014). Efeito do tratamento alcalino de fibras de curauá sobre as propriedades de compósitos de matriz biodegradável. Polímeros: Ciência e Tecnologia, 24(3), 388-394. http://dx.doi.org/10.4322/ polimeros.2014.024

5. Nadlene, R., Sapuan, S. M., Jawaid, M., Ishak, M. R., \& Yusriah, L. (2018). The effects of chemical treatment on the structural and thermal, physical, and mechanical and morphological properties of roselle fiber-reinforced vinyl ester composites. Polymer Composites, 39(1), 274-287. http://dx.doi.org/10.1002/ pc.23927.

6. Milanese, A. C., Cioffi, M. O. H., \& Voorwald, H. J. C. (2012). Flexural behavior of sisal/castor oil-based polyurethane and sisal/phenolic composites. Materials Research, 15(2), 191-197. http://dx.doi.org/10.1590/S1516-14392012005000019.

7. Mei, L. H., \& Oliveira, N. (2017). Caracterização de um compósito polimérico biodegradável utilizando Poli ( $\varepsilon$-caprolactona) e borra de café. Polímeros: Ciência e Tecnologia, 27(7), 99-109. https://doi.org/10.1590/0104-1428.2139.

8. Fernandes, J. R., Moisés, M. P., Girotto, E. M., Favaro, S. L., \& Radovanovic, E. (2017). Nanopartículas de sílica silanizada como compatibilizante em compósitos de fibras de sisal/ polietileno. Polímeros: Ciência e Tecnologia, 27(spe), 61-69. https://doi.org/10.1590/0104-1428.2249.

9. Spadetti, C., Silva, E. A., Fo., Sena, G. L., \& Melo, C. V. P. (2017). Propriedades térmicas e mecânicas dos compósitos de Polipropileno pós-consumo reforçados com fibras de celulose. Polímeros: Ciência e Tecnologia, 27(spe), 84-90. https://doi. org/10.1590/0104-1428.2320.

10. Mano, B., Araujo, J. R., De Paoli, M.-A., Waldman, W. R., \& Spinace, M. A. (2013). Mechanical properties, morphology and thermal degradation of a biocomposite of polypropylene and curaua fibers: coupling agent effect. Polimeros: Ciência e Tecnologia, 23(2), 161-168. http://dx.doi.org/10.1590/S010414282013005000025.

11. Vasco, M. C., Claro, S., No., Nascimento, E. M., \& Azevedo, E. (2017). Gamma radiation effect on sisal/polyurethane composites without coupling agents. Polímeros: Ciência e Tecnologia, 27(2), 165-170. http://dx.doi.org/10.1590/01041428.05916.

12. de Farias, J. G. G., Cavalcante, R. C., Canabarro, B. R., Viana, H. M., Scholz, S., \& Simão, R. A. (2017). Surface lignin removal on coir fibers by plasma treatment for improved adhesion in thermoplastic starch composites. Carbohydrate Polymers, 165, 429-436. http://dx.doi.org/10.1016/j.carbpol.2017.02.042. PMid:28363569.

13. Scalici, T., Fiore, V., \& Valenza, A. (2016). Effect of plasma treatment on the properties of Arundo Donax L. leaf fibres and its bio-based epoxy composites: a preliminary study. Composites. Part B, Engineering, 94, 167-175. http://dx.doi. org/10.1016/j.compositesb.2016.03.053.

14. Azevedo, E. C., Nascimento, E. M., Chierice, G. O., Claro, S., No., \& Lepienski, C. M. (2013). UV and gamma irradiation effects on surface properties of polyurethane derivate from castor oil. Polímeros Ciência e Tecnologia, 23(3), 305-311. http://dx.doi.org/10.4322/polimeros.2013.087.

15. Marinho, N. P., Nascimento, E. M., Nisgoski, S., Magalhães, W. L. E., \& Neto, C. S., \& Azevedo, E. C. (2013). Caracterização física e térmica de compósito de poliuretano derivado de óleo de mamona associado com partículas de bambu. Polímeros: Ciência e Tecnologia, 23(2), 201-205. https://doi.org//10.4322/ S0104-14282013005000007.

16. Merlini, C., Soldi, V., \& Barra, G. M. O. O. (2011). Influence of fiber surface treatment and length on physico-chemical 
properties of short random banana fiber-reinforced castor oil polyurethane composites. Polymer Testing, 30(8), 833-840. http://dx.doi.org/10.1016/j.polymertesting.2011.08.008.

17. Zau, M. D. L., Vasconcelos, R. P., Giacon, V. M., \& Lahr, F. A. R. (2014). Avaliação das propriedades química, física e mecânica de painéis aglomerados produzidos com resíduo de madeira da Amazônia - Cumaru (Dipteryx Odorata) e resina poliuretana à base de óleo de mamona. Polímeros: Ciência e Tecnologia, 24(6), 726-732. http://dx.doi.org/10.1590/01041428.1594

18. Orellana, E., Figueiredo, A., Fo., Péllico, S., No., \& Vanclay, J. K. (2017). A distance-independent individual-tree growth model to simulate management regimes in native Araucaria forests. Journal of Forest Research, 22(1), 30-35. http://dx.doi. org/10.1080/13416979.2016.1258961.

19. Fichino, B. S., Pivello, V. R., \& Santos, R. F. (2017). Trade-offs among ecosystem services under different pinion harvesting intensities in Brazilian Araucaria Forests. The International Journal of Biodiversity Science, Ecosystem Services \& Management, 13(1), 139-149. http://dx.doi.org/10.1080/215 13732.2016.1275811.

20. Boff Zortéa-Guidolin, M. E., Piler de Carvalho, C. W., Bueno de Godoy, R. C., Mottin Demiate, I., \& Paula Scheer, A. (2017). Influence of extrusion cooking on in vitro digestibility, physical and sensory properties of brazilian pine seeds flour (Araucaria Angustifolia). Journal of Food Science, 82(4), 977-984. http:// dx.doi.org/10.1111/1750-3841.13686. PMid:28339105.

21. Lima, E. C., Royer, B., Vaghetti, J. C. P., Brasil, J. L., Simon, N. M., Santos, A. A., Jr., Pavan, F. A., Dias, S. L. P., Benvenutti, E. V., \& Silva, E. A. (2007). Adsorption of Cu(II) on Araucaria angustifolia wastes: determination of the optimal conditions by statistic design of experiments. Journal of Hazardous Materials, 140(1-2), 211-220. http://dx.doi.org/10.1016/j. jhazmat.2006.06.073. PMid:16876938.

22. Poletto, M., Zattera, A. J., Forte, M. M. C., \& Santana, R. M. C. (2012). Thermal decomposition of wood: Influence of wood components and cellulose crystallite size. Bioresource Technology, 109, 148-153. http://dx.doi.org/10.1016/j. biortech.2011.11.122. PMid:22306076.

23. Brasil, J. L., Ev, R. R., Milcharek, C. D., Martins, L. C., Pavan, F. A., Santos, A. A., Jr., Dias, S. L., Dupont, J., Zapata Noreña, C. P., \& Lima, E. C. (2006). Statistical design of experiments as a tool for optimizing the batch conditions to $\mathrm{Cr}(\mathrm{VI})$ biosorption on Araucaria angustifolia wastes. Journal of Hazardous Materials, 133(1-3), 143-153. http://dx.doi. org/10.1016/j.jhazmat.2005.10.002. PMid:16297543.
24. Ahmed Sbia, L., Peyvandi, A., Soroushian, P., Balachandra, A. M., \& Sobolev, K. (2015). Evaluation of modified-graphite nanomaterials in concrete nanocomposite based on packing density principles. Construction \& Building Materials, 76, 413-422. http://dx.doi.org/10.1016/j.conbuildmat.2014.12.019.

25. Azevedo, E. C., Claro, S., No., Chierice, G. O., \& Lepienski, C. M. (2009). Aplicação de indentação instrumentada na caracterização mecânica de poliuretana derivada de óleo de mamona. Polímeros: Ciência e Tecnologia, 19(4), 336-343. http://dx.doi.org/10.1590/S0104-14282009000400014.

26. Azevedo, E. C., Chierice, G. O., Claro, S., No., Soboll, D. S., Nascimento, E. M., \& Lepienski, C. M. (2011). Gamma radiation effects on mechanical properties and morphology of a polyurethane derivate from castor oil. Radiation Effects and Defects in Solids, 166(3), 208-214. http://dx.doi.org/10. 1080/10420150.2010.525235.

27. Ornaghi, H. 1., Jr., Moraes, Á. G. D. O., Polletto, M., Zattera, A. J., \& Amico, S. C. (2016). Chemical composition, tensile properties and structural characterization of buriti fiber. Cellulose Chemistry and Technology, 50(1), 15-22. Retrieved in 2018, April 10, from http://www.cellulosechemtechnol.ro/ pdf/CCT1(2016)/p.15-22.pdf

28. Li, X., Lei, B., Lin, Z., Huang, L., Tan, S., \& Cai, X. (2014). The utilization of bamboo charcoal enhances wood plastic composites with excellent mechanical and thermal properties. Materials \& Design, 53, 419-424. http://dx.doi.org/10.1016/j. matdes.2013.07.028.

29. Trovati, G., Sanches, E. A., Neto, S. C., Mascarenhas, Y. P., \& Chierice, G. O. (2010). Characterization of polyurethane resins by FTIR, TGA, and XRD. Journal of Applied Polymer Science, 115(1), 263-268. http://dx.doi.org/10.1002/app.31096.

30. Luo, Z., Li, P., Cai, D., Chen, Q., Qin, P., Tan, T., \& Cao, H. (2017). Comparison of performances of corn fiber plastic composites made from different parts of corn stalk. Industrial Crops and Products, 95, 521-527. http://dx.doi.org/10.1016/j. indcrop.2016.11.005.

31. Obi Reddy, K., Uma Maheswari, C., Shukla, M., Song, J. I., \& Varada Rajulu, A. (2013). Tensile and structural characterization of alkali treated Borassus fruit fine fibers. Composites. Part B, Engineering, 44(1), 433-438. http://dx.doi.org/10.1016/j. compositesb.2012.04.075.

Received: Apr. 10, 2018 Revised: Feb. 12, 2019 Accepted: Apr. 04, 2019 